\title{
O dośWIADCZENIU ŚMIERCI w POEZJI EdY OstrowsKIEJ
}

Życiowa mądrość uczy nas, że aby zachować duchową równowagę nie powinniśmy wiedzieć zbyt wiele o ciemnych stronach życia. Od tego, co poraża w nas wolę przetrwania, instynktownie odwracamy oczy. Zdarza się jednak czasem, że następuje zmiana spojrzenia: zaczynamy widzieć to, czego nie powinniśmy widzieć, więcej: nie możemy oderwać oczu, od tego co się przed nami odsłoniło. Świat staje się przedmiotem osobliwej tanatycznej kontemplacji. Granica ryzyka zostaje przekroczona ciemność zaczyna „wysysać” duszę̨ 2 .

Słowa Stefana Chwina umieszczone w książce Samobójstwo jako doświadczenie wyobraźni nakreślają dramat prawie każdej osobowości dewiacyjnej, która — jak napisał Colin Wilson w książce Outsider — „sięga wzrokiem zbyt daleko i widzi zbyt wiele" ${ }^{3}$. Dewiant (autentyczny obcy — chory psychicznie, człowiek dotknięty autyzmem, włóczęga, wyrzutek, tramp, trubadur, nałogowy alkoholik, narkoman, który odrzucił zalecane cele kulturowe, a jego zachowanie nie odpowiada normom instytucjonalnym $^{4}$ ), wędrując przez piekło swojej duszy, dokonuje samoanalizy. Przenika w głąb człowieczeństwa, przekonuje się, że jest jedynym człowiekiem, który wie, że jest chory, żyjąc w środowisku niezdającym sobie sprawy ze swej choroby. W wyniku społecznego osamotnienia dochodzi często u niego do napięcia nerwowego, które sprawia, że odrzucony przez społeczeństwo myśli o samobójstwie ${ }^{5}$ — jak stwierdził Chwin — zaczyna kontemplować śmierć. „Ja”, które myśli o samobójstwie, nie od razu go dokonuje. Odebranie sobie życia bowiem, po pierwsze — jest efektem długiego, duchowego procesu, po drugie — na co zwrócił uwagę Wilson — każdemu dewiantowi (outsiderowi) zdarzają się chwile dziwnej jasności widzenia, przebłyski spokoju i harmonii, momenty porozumienia się ze światem:

\footnotetext{
${ }^{1}$ Katarzyna Niesporek - doktorantka w Zakładzie Literatury Współczesnej Uniwersytetu Śląskiego. Studia polonistyczne ukończyła na podstawie pracy o poezji Marcina Świetlickiego. W kręgu jej naukowych zainteresowań znajduje się poezja polska drugiej połowy XX wieku, a także zagadnienia najnowszej kultury literackiej. Artykuły naukowe i recenzje ogłaszała w tomach zbiorowych i czasopismach. Jest autorką książki „Ja" Świetlickiego (2014) i współredaktorką tomu zbiorowego Literatura popularna, t. 2: Fantastyczne kreacje światów (2014).

${ }^{2}$ S. Chwin, Wojaczek. Samobójstwo jako doświadczenie wyobraźni, [w:] tenże, Samobójstwo jako doświadczenie wyobraźni, Gdańsk 2010, s. 124.

${ }^{3}$ C. Wilson, Outsider, przekł. M. Tarczewska, Kraków 1959, s.17.

${ }^{4}$ Por. R. K. Merton, Teoria socjologiczna i struktura społeczna, przekł. E. Morawska, J. Wertenstein-Żuławski, Warszawa 2002, s. 217-218.

${ }^{5}$ C. Wilson, dz. cyt., s. 55 .
} 
Niekiedy napięcie nerwowe sprawia, że outsider-artysta myśli o samobójstwie, lecz zanim do tego dojdzie, wszechświat znów nabiera sensu — outsider ma przebłysk celowości istnienia ${ }^{6}$.

Rozmyślanie doprowadza dewianta do proroczego objawienia, którego nie może przeżyć człowiek o zdrowym umyśle. Wilson, powołując się na słowa Williama James’a z książki Doświadczenia religijne, napisał najpierw: „Umysł tzw. chorobliwy obejmuje większą skalę doświadczenia, jego pogląd góruje nad zdrowomyślnością”", następnie, uzupełniając rozumowanie James’a, dodał: „zdrowe myślenie jest płytkie, głupie i krótkowzroczne"8. Oto dlaczego dewiant stara się go unikać, odcina się od relacji społecznych. Mimo że jest zamknięty w czterech ścianach swojego mieszkania czuje się lepszy od insiderów. Mówi, chcąc wytłumaczyć się z przyjętej przez siebie postawy:

Niech tylko każdy człowiek popatrzy szeroko otwartymi oczami na świat, w którym żyje, a natychmiast stanie się outsiderem. Zacznie od tego, że będzie myślał, iż „sięga wzrokiem zbyt głęboko i widzi zbyt wiele”, a skończy na stwierdzeniu, że inni ludzie nie umieją sięgać wzrokiem tak głęboko i widzieć tak wiele?.

Osoba o chorym umyśle nieustannie rozmyśla o swoim wnętrzu. Daje w ten sposób świadectwo swojej odwagi. Odwaga ta jednak może prowadzić do przekroczenia wyznaczonej granicy — gry ze śmiercią. Śmierć z kolei postrzegana jest jako wyzwolenie człowieka:

[...] do wolności najbardziej zbliża się człowiek w obliczu śmierci: wie o tym samobójca lub skazaniec, dla żyjącego, pełnego energii człowieka — to prawie niepodobieństwo ${ }^{10}$.

Wolności wydaje się poszukiwać outsiderka Eda Ostrowska — poetka, która w swoim doświadczeniu egzystencjalnym przechodzi przez stany graniczne: próby samobójcze, uzależnienie od narkotyków, zapaść, śpiączkę. Nie odnajdując porozumienia ze światem, samotna zamyka się w Abramowicach w szpitalu psychiatrycznym, w którym pisze dziennik Oto stoje przed toba w deszczu ciała. Autorka zapisuje w nim swoje huśtawki nastrojów. Od napięcia przez depresję do myśli samobójczych:

Jednego w życiu żałuję, że żyję... trzeba to skreślić... trzeba to zapisać dużymi literami, drukowanymi... „Gdzie jest pętla? Miała być pętla”, „Była jest i będzie na Zana”, „Nie, nie”, „Jakie ty masz imię Edzia?”, „Pisze się Edwarda, maluje się Edzia, a mówi Eda...” „Światło, jedna mucha, dwie muchy, tak niewiele w życiu potrzeba - pasek i drzewo" ${ }^{11}$.

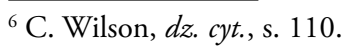

${ }^{7}$ W. James, Doświadczenia religijne, przekł. J. Hempel, Warszawa 1958, s. 150.

${ }^{8}$ C. Wilson, $d z$. cyt., s. 143.

${ }^{9}$ Tamże, s. 261.

${ }^{10}$ Tamże, s. 48.

${ }^{11}$ E. Ostrowska, Oto stoje przed toba $w$ deszczu ciała, Warszawa 1983, s. 36.

9 maja 2013 roku ukazało się nowe, poprawione wydanie tej książki, tym razem zatytułowane Oto stoje $w$ deszczu ciała [dziennik studentki]. Korzystam jednak z wersji pierwotnej dziennika, gdyż z nowego wydania wiele istotnych fragmentów dla interpretacji utworów Edy Ostrowskiej zostało usuniętych. 


\title{
W innym miejscu dodaje:
}

Zdzisiu, zapamiętaj sobie: jedno, co warto, to umrzeć; minęly trzy minuty, nie zmieniłam zdania, przeleciało, nie wiem ile, ptaków, nie zmieniłam zdania, minęłam ludzi mądrzejszych i głupszych od siebie o jedno pozwolenie wyjścia, niby drobnostka, a ile płaczu, ile ściskania rąk powyżej nadgarstka [...].

Przeszłam wiele kilometrów, minęłam wiele rozbitych garnków, porzuconych trepów i zapewniam cię: jedyne, co warto, to umrzeć' ${ }^{12}$.

\section{Zadając wciąż egzystencjalne pytanie, pisze:}

Nadziejo, moja nadziejo, tęsknoto, moja tęsknoto... Biały stół, a tu mowa o nadziei, Boże!, tu nie ma nic szlachetnego [...], nie mogę pisać, nie wiem dlaczego... „Jarzębina czerwona”, „Salowo, zatańczymy”, „Koniec grania, pętla będzie”, „Włączamy telewizor”, „Pętla”, pętla — wystarczy jedna na Zana; żyć czy umierać [podkr. — K.N.] — pytanie za milion, stawka nie za wysoka $[\ldots]^{13}$.

Poetka jest przekonana o istnieniu lepszego życia po drugiej stronie. Nie mając jednak na tyle odwagi, by popełnić samobójstwo, odnajduje przestrzenie alternatywne, które pozwalają jej żyć na krawędzi, igrać z życiem i śmiercią. Przekraczając granice „normalności”, jej umysł ulega transgresji, która dokonuje się za sprawą utraty świadomości. „Ja” egzystuje w dwóch światach. Rzeczywistym i tym, który przynosi jej ulgę — urojonym, objawiającym się po zażyciu „narkotycznych substancji”. Poetka pisze sama o sobie:

Już przypominam sobie

znałam kiedyś kobietę

która kochała się w maku

miała bardzo piękną twarz

chociaż nigdy jej nie widziałam

\begin{abstract}
Znamienna wydaje się adnotacja znajdująca się w nawiasie kwadratowym, dodana do tytułu nowego wydania notatek poetki. Można tym samym przypuszczać, że Ostrowska — teraz już, z perspektywy pisarki doświadczonej, której choroba psychiczna z lat młodości została stłumiona - owym dopiskiem chciała zaznaczyć, że jej ówczesna twórczość była jeszcze wtedy, w latach 80 (Ostrowska miała bowiem niespełna dwadzieścia lat), nie do końca dojrzała, bo pisana pod wpływem młodzieńczych uniesień, narkotycznych deliriów, psychodelicznych „dołów” i umysłowej nieświadomości. W wywiadzie dla „Opcji” zapytana dlaczego zdecydowała się na ponowne wydanie swojego dziennika, odpowiedziała: „W 2010 roku obudziłam się z depresji, stuknęła przy okazji pięćdziesiątka, druga młodość, no i odleciałam. W zasadzie nie musiałam przenosić się w przeszłość, ona stała się teraźniejszością. Poczułam się tożsamą Edką — poetką, outsiderką, ryzykantką, prowokatorką. Znalazłam własną skórę, leżała w kącie pod miotłą dziejów. Zatem naturalny był powrót do publikacji z okresu dzieci-kwiatów. Zapragnęłam obwieszczać, co już zostało powiedziane, w sposób świeży i dojrzały. Z książki w nowej redakcji cieszę się niezmiernie. Wszystko robię spontanicznie, intuicyjnie, tak też było ze wznowieniem dziennika. Poczułam impuls, żeby wklepać do komputera. Przepisując na sucho, bez sekundy zastanowienia, błyskawicznie cięłam, szlifowałam stylistykę oraz dziergałam interpunkcję. A kiedy ukończyłam dzieło, zapragnęłam drukować. Dokładnie trzydzieści lat od pierwszego wydania. Bosko". Zob. Petnia. Z Eda Ostrowska rozmawia Katarzyna Zdanowicz-Cyganiak,„Opcje” 2013, nr 4(93), s. 156-158.

12 Tamże, s. 40.

${ }^{13}$ Tamże, s. 46.
\end{abstract}




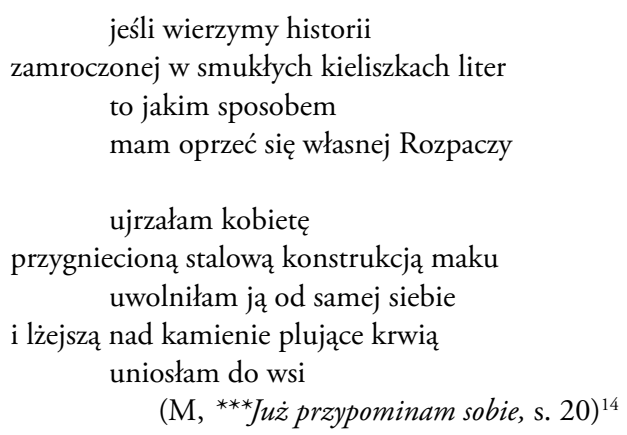

Pod cytowanym wierszem z tomu Matmazja (wydanym w 1988 roku), widnieje znamienny zapis: „Lublin 14.11 .80 r. (obraz)”. Adnotacja umieszczona w nawiasie $\mathrm{z}$ jednej strony sugeruje, że poetka opisuje dzieło sztuki oglądane w danej chwili i to ono stanowi inspirację do napisania wiersza, z drugiej strony, że rzeczywistość z obrazu to jedynie widzenie autorki Echolalii, którego bohaterka przypomina samą Ostrowską — kobietę, „kochającą się w maku”, „przygniecioną stalową konstrukcją maku”. Mak to z kolei kwiat narkotyczny, działający na zmysły (szczególnie kobiety). Jego ziarna zaspokajają wewnętrzny i fizyczny głód osoby uzależnionej, ale też, mimo całego swojego powierzchownego uroku, posiada destrukcyjne (właśnie przygniatające) właściwości. Pod przykrywką ekstazy przyspieszają one proces umierania człowieka. W narkotycznych halucynacjach, mimo że bohaterka patrzy na siebie, to definiuje rysy twarzy kogoś innego. Zamykając je w kategoriach estetycznych stwierdza, że owszem są atrakcyjne, ale dla niej nierozpoznawalne. Nie może ich nikomu przyporządkować. Bohaterka wiersza nie zdaje sobie sprawy, że obraz, który widzi, to lustrzane odbicie jej samej. Po zażyciu narkotyków, doświadczając halucynacji oraz patrząc w lustro, rozszczepia się na "ja” rzeczywiste i urojone. Spoglądając na uwięzioną w obrazie kobiecą postać całą w makach (owe „ja" urojone), doskonale rozumiejąc przyczyny jej ubezwłasnowolnienia („,...] jakim sposobem mam oprzeć się własnej Rozpaczy”), w swoim umyśle próbuje ocalić kobietę, wyprowadzić ją na wolność (nie zdaje sobie sprawy, że w rzeczywistości ratuje siebie). Poetka w tym celu wciela się w rolę empatycznego, wszechmocnego wybawiciela, który pragnie uwolnić z opresji urojoną bohaterkę: „uwolniłam ją od samej siebie / i lżejszą na kamienie plujące krwią / uniosłam do wsi”. Po chwili jednak, znając przyczyny uwięzienia kobiety w obrazie, relacjonuje:

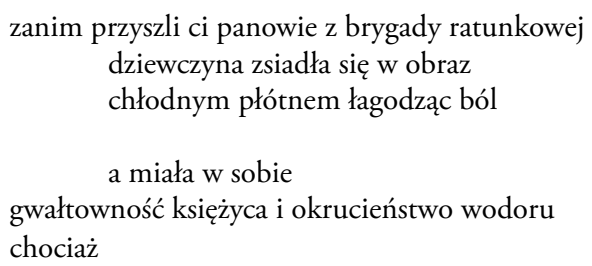

\footnotetext{
${ }^{14}$ Wszystkie przytoczone w artykule utwory poetyckie pochodzą z tomu E. Ostrowska, Matmazja, Katowice 1988. Po skrócie M, podaję tytuł wiersza i numer strony.
} 
była zielona jak rzeka

i tkliwiej płynęła niż najczulsze światło

(M, ***uż przypominam sobie, s. 20)

Ocaleniem dla „ja” z płótna nie jest brygada ratunkowa (ze szpitala psychiatrycznego). Ale zastygnięcie w obraz, bezruch, nieczynność, czyli śmierć. Podobnie jak płótno obrazu przynosi ukojenie, daje kres rozpaczy. Dziewczyna z obrazu może być poetką. Wszystko się zgadza - narkotyki, rozpacz, wrażliwość, niemożność poradzenia sobie z życiem, rozpacz, ból. Tylko twarz jest nierozpoznawalna, dlatego że jest twarzą kobiety umarłej. Zagłębiając się w obraz (obojętnie czy jest on dziełem sztuki czy narkotyczną halucynacja), bohaterka wiersza przygląda się przestrzeni uchwyconej w określonym momencie i zatrzymanej. Rzeczywistości, która choć zewnętrznie piękna, wewnątrz jest martwa.

Fascynację życia na krawędzi podsycają u autorki Baranka zabitego przynoszące chwile wytchnienia i rozkoszy „śmiercionośne używki”. „Ja”, pokonując kolejno wyznaczone przez siebie etapy zagłębiania się w śmierć, coraz bardziej ryzykuje. Igrając zżyciem, odbywa narkotyczne wędrówki, zanurza się w świat, który jest halucynacją:

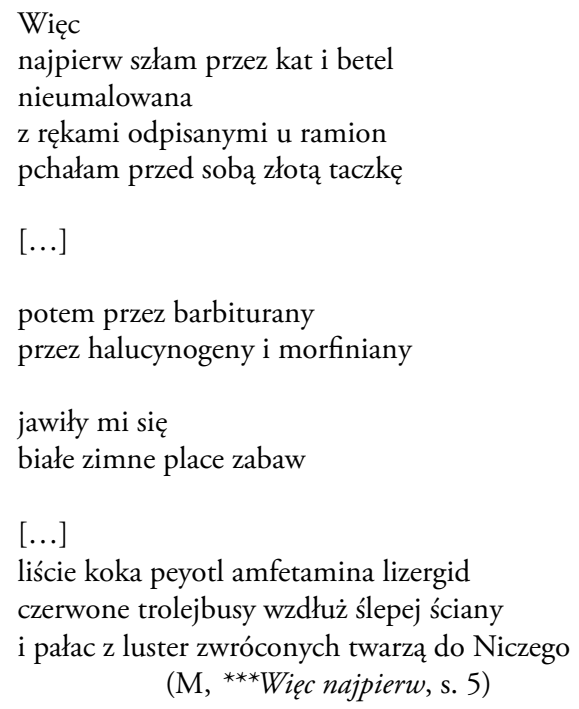

„Ja" Ostrowskiej rozpoczyna swoje wędrowanie od łagodnych używek. Ociera się przez kat (krzew z liśćmi zawierającymi alkaloidy, z których sporządza się napoje pobudzające) i betel (nadmierne spożywanie prowadzi do nałogu, ceniony w Azji Południowo-Wschodniej), wprowadzając siebie w stan lekkiego otępienia. Przechodząc na wyższy etap, bohaterka poi się barbituranami, halucynogenami, morfinianami - lekami przeciwbólowymi, środkami nasennymi. Znieczulając ból istnienia, zagłębia się w halucynacje: „jawiły mi się / białe zimne place zabaw”. „Place zabaw” odnoszą się raczej do przeżyć, łączą się z dzieciństwem. Tymczasem w wizjach „ja” pojawiają się biel i zimno, które można kojarzyć ze śmiercią. Zamiast ,jawiły mi się / białe zimne 
place zabaw”, dokonując parafrazy słów Ostrowskiej, można powiedzieć: ,jawiły mi się / śmiertelne place zabaw” albo „place zabaw śmierci”. W przestrzeni „normalności” obraz ten wydaje się irracjonalny. Sytuacja przedstawia się zaś odwrotnie, kiedy podobne wizje pojawiają się w chorym umyśle, gdzie śmierć przejawia się we wszystkich elementach tworzących rzeczywistość.

Następnie ,ja” Ostrowskiej, mierząc wyżej, wspomina o liściach koka, peyotlu, amfetaminie, lizergidzie. To silne narkotyki, powodujące długotrwałe pobudzenie oraz wywołujące irracjonalne omamy, takie jak obraz „czerwonych trolejbusów wzdłuż ślepej ściany". Bohaterka wierszy w swoim świecie halucynacji dostrzega także pomieszczenie $\mathrm{z}$ lustrami. Tym razem jednak - inaczej niż miało to miejsce w poprzednim utworze - rozpoznaje w odbiciu siebie, po czym stwierdza, że lustra są zwrócone do „Niczego”. Nazwanie siebie „Niczym” oznacza zatracenie poczucia wartości. Wyraz ten zostaje jednak zapisany przez poetkę wielką literą, poprzez co nobilituje ona samą siebie. Bycie „Niczym” w oczach ludzi „normalnych” jest często równoznaczne z byciem „innym”. Dlatego też „ja”, odcinając się od świata, ale będąc pewnym swoich decyzji, dąży do odosobnionych przestrzeni narkotycznych, czując się dobrze jedynie $\mathrm{w}$ cieniu śmierci ${ }^{15}$.

Swoją „inność” poetka próbuje wyjaśnić w wierszu rozpoczynającym się od słów ***esteśmy nierealni widmowi:

\section{Jesteśmy nierealni widmowi \\ w nas biorą początek ulice \\ kołyszą się latarnie \\ eksplodują miasta}

$\left(\mathrm{M},{ }^{* * *}\right.$ Jesteśmy nierealni widmowi, s. 45)

W cytowanym utworze bohaterka wypowiada się w imieniu wszystkich podobnych do niej narkomanów. Używając sformułowań „nierealni”, „widmowi”, podkreśla statut „innych”, outsiderów. Tacy jak osoba mówiąca znikają, kiedy pod wpływem narkotyków zanurzają się w nierealnej rzeczywistości. „Ja”, określając siebie przymiotnikiem od rzeczownika „widmo", przedstawia się jako nieuchwytny byt połowiczny, egzystujący w „zawieszeniu”, w przestrzeni pomiędzy życiem a śmiercią. Ale też jako istota wiecznie i beznadziejnie konająca, nie pretendująca do zaznania wiecznego spokoju. Nie odczuwając potrzeby nieodwracalnego przejścia na stronę śmierci, stawia niebezpieczne kroki na granicy, igra z życiem, droczy się z ostatecznością. Narkotyki są dla "ja” przepustką do stania się upragnionym „nierealnym” $i$,widmowym”. Bohaterka wiersza w stanie euforycznego poczucia nierzeczywistości, chociaż nieuchwytna i bliska śmierci, roi sobie, że jest kimś kluczowym dla świata. Nie mogąc jednak zdecydować się na śmierć, zostaje widmem. Nie chce zatracić ludzkich pierwiastków: „w nas biorą początek ulice”. Wizje doznawane przez bohaterkę tych wierszy, stojącą nad przepaścią w narkotycznym świecie, są pełne paradoksalnych halucynacji: „koły-

15 Poszerzoną interpretację utworu rozpoczynającego się od słów ***Więc najpierw można znaleźć w: K. Niesporek, Stany graniczne „ja” w poezji Edy Ostrowskiej, [w:] Transgresywne monstrum, red. M. Fołta i D. Bastek, Katowice 2013, 175-195. 
szą się latarnie / eksplodują miasta”. W przestrzeni wyobrażonej wszystko odbywa się inaczej niż w rzeczywistości, obowiązuje odwrócony porządek świata, odpowiadający outsiderom.

W dalszej części wiersza autorka Echolalii woła:

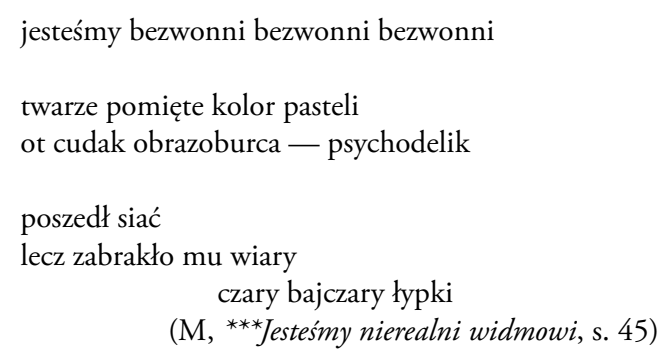

Bohaterka utworu trzykrotnym i bardzo przekonującym zawołaniem o swojej bezwonności zapewnia o utracie jednego z fizjologicznych elementów związanych z ciałem człowieka. Brak zapachu świadczy o zatraceniu cielesności. „Ja” składa się zatem tylko z duszy. Nie jest człowiekiem z krwi i kości, ale duchem czy widmem. Bezwonność może jednak także oznaczać utratę przez narkomana węchu. To konsekwencja zażywania psychoaktywnych materii. Bezzapachowe są również narkotyki, takie jak: amfetamina, kokaina i heroina. Nieodczuwanie zapachu świadczy zatem, że ma się do czynienia z narkotycznymi proszkami. Sam termin „bezwonność” jest więc ważny dla psychodelików. Ich wygląd zewnętrzny został z kolei opisany w dalszych wersach: „twarze pomięte / kolor pasteli”. Określenie „pomięte” odnosi się prawdopodobnie do stanu skóry - inaczej postarzałe, zmarszczone i zniszczone. Pastelowa barwa z kolei dotyczy ciała, wiąże się z przymiotnikiem „widmowy”. Pastelowy to bladawy, stonowany, prawie niewidoczny. Wszystkie te określenia odnoszą się do wyniszczonego zewnętrznie narkomana, który nie potrafi dostosować się do ogólnie obowiązujących norm. Sprzeciwiając się światu, ucieka do swojej rzeczywistości, starzejąc się, blednąc, wycofuje się, ale ostatecznie nie znika. Egzystuje za to w umysłowej przestrzeni pomiędzy życiem a śmiercią. Poruszając się po krawędzi, czasami ujawnia się i daje o sobie znać. Taka też jest natura widma.

O umieraniu w stanie narkotycznego uniesienia Ostrowska pisze, nawiązując do swoich osobistych doświadczeń:

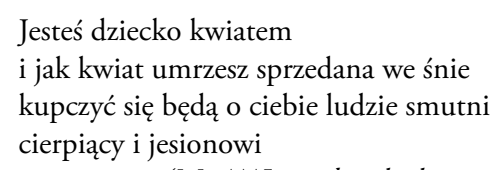

„Ja”, do którego zwraca się podmiot, przynależąc do kontestacyjnego ruchu dziecikwiatów, zostaje uwikłane w materie psychoaktywne — w sposób szczególny z przywoływanym wielokrotnie w wierszach Edy makiem. Uzależnieni są również w jakiś 
sposób podobni do kwiatów. Przede wszystkim łączy ich sposób umierania. Śmierć upomina się bowiem o nich we śnie, w psychodelicznych wędrówkach, w momentach utraty świadomości. Narkotyczne kwiaty, takie jak mak, wprowadzają psychodelika w ukojenie, fascynujące uniesienia, przygotowując jednocześnie dla niego tragiczną pułapkę. W stanach pobudzających halucynacji, „ja” nie zdaje sobie sprawy, że w rzeczywistości, z której ucieka, rozgrywa się walka o jego życie, toczona z nią przez „ludzi smutnych / cierpiących i jesionowych". Ci więc, od których outsider stroni, paradoksalnie odgrywają kluczowe role w jego egzystencji.

W dalszej części utworu podmiot przestrzega ,ja”:

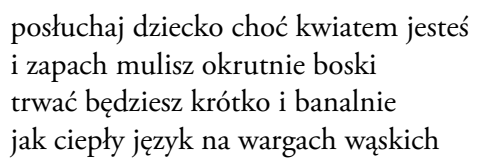

W tym fragmencie osoba mówiąca, wcielając się w rolę nauczyciela-przewodnika, wręcz mędrca („posłuchaj dziecko”), przypomina o oczywistej przemijalności. Niezależnie od zewnętrznego piękna, śmierć dotyczy zarówno natury — narkotycznych kwiatów, które w ostatecznym rozrachunku więdną albo stają się bezwonnym proszkiem, urokliwym tylko dla narkomanów - jak i człowieka, potrafiącego odnaleźć siebie jedynie wtedy, gdy karmi się narkotykami, zanurzając się w swojej odosobnionej rzeczywistości. „Ja” nie uznaje jednak naturalnego przemijania, bo w swojej „inności” poszukuje ekstremalnych doświadczeń granicznych. Bohaterka wierszy świadoma istnienia śmierci, wciąż się o nią ociera.

W niewygodnej prawdzie przemijania podmiot mówiący pozostawia przebłyski nadziei. Mówi do straceńców:

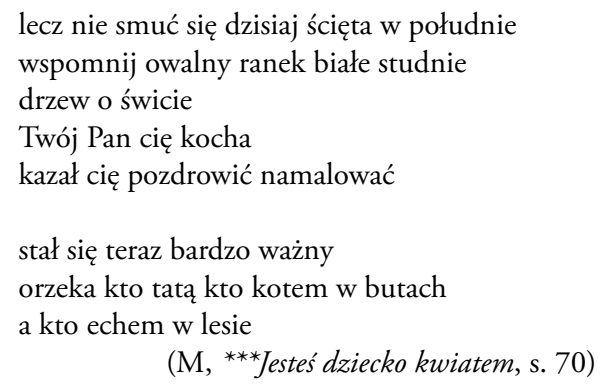

Znamienne są dwa ostatnie wersy utworu. Skoro Bóg decyduje o tym „kto tatą / kto kotem w butach / a kto echem w lesie", analogiczne orzeka także, kto jest narkomanem, psychodelikiem, outsiderem. Ostatecznie więc to Stwórca skazuje swoich wybranych na tragiczny los. Osoba mówiąca zapewnia jednak dziecko-kwiat o miłości Boga. Przekonuje je o boskiej pamięci: „kazał cię pozdrowić namalować”. Rozkaz namalowania „ja” wiąże się z omówionym już utworem rozpoczynającym się od słów 
*** Ju̇ przypominam sobie. Dziecko-kwiat to kobieta o pięknej twarzy, kochająca się w maku, „przygnieciona stalową konstrukcją maku”. Chroniąc siebie przed ekipą ratunkową (prawdopodobnie ze szpitala psychiatrycznego), zastygła na zawsze w obraz. Taka była wola Boża.

Umarła zwraca się jednak do Stwórcy w następnym utworze:

Słuchaj mnie Boże

i kołysz lalkami trzciny

a z ust niech Ci się wyrywa uryna i złote bąki kobiet

tak oto jestem

martwa jak kapelusz na wodzie w opalu żab

nienawidzę siebie samej

księżnej drewnianej w ogniu basujących luster

(M, ***Stuchaj mnie Boże, s. 54)

„Ja”, chociaż zastygłe w przestrzeń obrazu i martwe dla ludzi, wydobywa głos jakby z zaświatów. Zapewnia o swoim niekończącym się istnieniu: „tak oto jestem martwa jak kapelusz na wodzie w opalu żab”. Bohaterka, chociaż nieżywa, istnieje. Została obdarzona zdolnością unoszenia się. Zachowuje się więc jak widmo. „Ja” jako duch jest istotą bez ciała. Ciało zaś razem z umarłą twarzą kobiety zostało uwiecznione na obrazie, na którym bohaterka wiersza, chociaż zewnętrznie piękna, wewnątrz jest pusta. Duch dziewczyny, nie chcąc opowiedzieć się ani po stronie życia, ani po stronie śmierci, unosi się, błądzi i poszukuje. „Ja”, podobnie jak za czasów egzystencji na ziemi, pozostaje rozdarte pomiędzy dwoma krańcowymi punktami. Porusza się w miejscu, które stanowi granicę pomiędzy życiem a śmiercią. To w nim bowiem czuje się najbezpieczniej.

Wkrótce jednak zjawia się Bóg, pragnący ocalić bohaterkę wierszy ze stanu „nierealności”, „widmowości”. Ta z kolei odpowiada następująco:

czy chcesz mnie kochać

kwiat w brzuchu miedzi księżyc co muli jęzory drzew

jak mogę zawierzyć Twym słowom

jeśli sprzedajesz suknię a wyceniasz fenomen

odejdź

zostaw w irysach

oddech zapach i miech konnicy

idź z Bogiem i nie pozwól swoim aniołom się upijać

(M, ***Stuchaj mnie Boże, s. 54)

„Ja" poetki, dziwiąc się zainteresowaniem Boga swoją osobą, nie rozumie, w jaki sposób istota ze sfery sacrum może koncentrować swoją uwagę na dewiantce, zażywającej narkotyki.Takich dziewczyn nie powinno się kochać. „Ja” Ostrowskiej, zdając 
sobie sprawę, że jest „księżną drewnianą” - marionetką, którą za sznurki pociąga Bóg, zarzuca mu, że uczynił z niej fenomen — coś, co poznaje się zmysłami, dotyka, ogląda i jest wystawione na ocenę. "Ja”, nie ufając zarówno istotom ludzkim i boskim, woła: ,jak mogę zawierzyć Twym słowom”. Po czym rozkazuje Bogu odejść tam, skąd przyszed — do uległych mu aniołów.

Kiedy jednak żywot dzieci-kwiatów staje się zagrożony, nawet kobieta-wariatka, mimo wcześniejszego odrzucenia Boga, jest zdolna do modlitwy — narkotycznych modłów:

\author{
Jezu miej w opiece \\ rozbite miseczki z woskiem narkomanów \\ ich krew formalinę cholerne sadzawki w psich oczach \\ ich piłki pingpongowe ich gałganiarstwo ich złoty piasek \\ w losowych woreczkach \\ Jezu daj hipisom \\ jeszcze jedną noc i dzień \\ i orzechowy stół do składania ikry \\ Ty wiesz \\ oni nie zaniedbują chorego księżyca zamku luster czy \\ polichromii \\ Jeśli Cię spytają \\ Kim są Ci? w jakim materiale rzeźbią? \\ Odpowiedz że są dziećmi i bawią się dłutem \\ a drzewo życia jest im uległe jak białe trąby nauk \\ (M, ***ezu miej w opiece, s. 16)
}

"Ja" zwraca się do Syna Bożego we własnych interesach. Prosi o ochronę dla narkomanów, jak również o łaskawe oko dla ich halucynogenów. Przedłużają bowiem, im życie, pozwalają udawać się w umysłowe, podświadome wędrówki. Umożliwiają także kochać miłością nieograniczoną. Miłością przede wszystkim zmysłową, cielesną. Dzieci-kwiaty są wierne swoim przekonaniom, często bardziej, aniżeli prawowierny człowiek manifestujący swoją wiarę w Boga. Bohaterka utworu prosi Chrystusa o błogosławieństwo ich narkotycznego życia, narkotyków, wszystkich białych proszków, które dla uzależnionego są jak starotestamentalna manna z nieba. Bóg w ten sposób zostaje uwikłany w narkotyczność przez „ja”. Wszystkie używki stanowią element świata stworzonego przez Boga. Następuje zatem uświęcenie narkotyków. Od teraz są one boskim pokarmem, wprowadzającym w stan świętego uniesienia, wyjątkowej ekstazy. Psychoaktywne materie nie zawsze jednak prowadzą jedynie do odurzenia. Bywa, że wyznaczona granica zostaje przekroczona i wtedy jest się o krok od śmierci. Wówczas narkotyczne modły przepełnione dumą, zmieniają się w szczerą, pokorną modlitwę: 
Umieram

ludzie kołują nad głową jak złote fusy

Idę do Ciebie Jezu

bez zrozumienia rzeczy

błagam Cię

miej pobłażanie dla głupców

a miłosierdzie dla oprawców

bo pośród chwastów wzrośnie zboże

i będą się cieszyć Twoje oczy

lecz serce w smutku nie ustanie

wołaj mnie wołaj mnie wołaj mnie!

choć jestem z drewna i bajcu

usta mam czułe na zmiłowanie

(M, ***Umieram, s. 46)

Słowa te mogą być również wypowiadane w stanie narkotycznego głodu osoby uzależnionej. To kulminacyjny moment, kiedy narkoman przestaje normalnie funkcjonować. „Ja”, zdając sobie sprawę z życia uchodzącego z jej ciała, z szacunkiem zwraca się do Chrystusa. Prosi o miłosierdzie. To chrześcijańskie, pełne wiary wołanie osoby konającej. Prośba „miej pobłażanie dla głupców / a miłosierdzie dla oprawców” jest podobna do tej, którą Chrystus wypowiedział na krzyżu: „Ojcze, przebacz im, bo nie wiedzą co czynią” (Łk 23, 34) ${ }^{16}$. Bohaterka Ostrowskiej doznaje wizji charakterystycznych dla człowieka umierającego. W oddali widzi Chrystusa, do którego trzykrotnie krzyczy, używając trybu rozkazującego: „,wołaj mnie wołaj mnie wołaj mnie!”. Pragnie usłyszeć zmysłowy, kojący głos Syna Bożego, chce także, aby jak najszybciej przyszedł kres jej męki na ziemi. „Ja”, błagając o zmiłowanie, prosi również o przebaczenie. Uzasadnia swoją prośbę, odwołując się do przypowieści biblijnych o siewcy ${ }^{17}$ : „bo pośród chwastów wzrośnie zboże”. Zbożem, dobrą rośliną, pożywieniem wśród zażywanych narkotyków, jest pokora, żal za wszystkie narkotyczne słabości, poczucie zawstydzenia osoby mówiącej wobec Istoty Najwyższej:

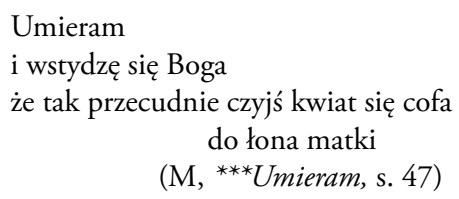

Umieranie w tym wierszu to raczej krótkotrwały proces, który można określić już nie jako wieczne konanie, czy narkotyczne wędrowanie, ale właściwy stan, trwający

${ }^{16}$ Pismo Święte Starego i Nowego Testamentu. Biblia Tysiaclecia, wyd. 5, Poznań 2000.

${ }^{17}$ Zob. Mt 13, 3-8; Mk 4, 1-9; Łk 8, 4-8. Tamże. 
określony ułamek czasu. To czas, po stwierdzeniu zgonu, który jest potrzebny duszy do przejścia drogi od życia do śmierci. Poetka opisuje ten moment — parafrazując słowa Ostrowskiej — jako „przecudne przemieszczanie kwiatu”. Mimo narkotycznych uwikłań bohaterki utworu, Bóg pozwala doznać jej, tym razem już nie narkotycznego, a boskiego, mistycznego uniesienia, w obliczu którego widzi także swoją nędzę i grzeszność.

„Ja", wspominając u progu śmierci egzystencję, kolejne etapy dewiacyjnej wędrówki, zdaje sprawę ze swojego istnienia:

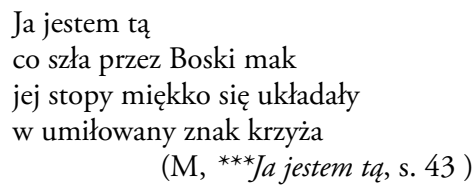

Poetka, zanurzając się w swoje życie, po raz kolejny łączy z narkotycznością Najwyższego. Obok maku tym razem pojawia się zupełnie niepasujący do narkotycznych przestrzeni „umiłowany znak krzyża”. Ponadto czerwony kwiat narkotyczny zostaje określony przez podmiot przymiotnikiem „Boski”, co uściśla proweniencję rośliny — mak został stworzony dla człowieka, jest darem Boga. Profanum więc bezpośrednio uzupełnia się ze sferą sacrum. Krzyż uświęca mak, ten zaś subtelnie bezcześci najważniejszy symbol religii chrześcijańskiej. Oba rekwizyty — zarówno jeden z najbardziej rozpoznawalnych atrybutów narkomanów, jak również nieodzowny symbol męki i śmierci Mesjasza, odnajdują swe źródło w Bogu, są więc z natury dobre. Mając wolność wyboru, „ja” nie odrzuca ani maku, ani krzyża. Próbuje żyć w zgodzie z jednym i z drugim, co nie zdoła uchronić jej przed tragicznym losem:

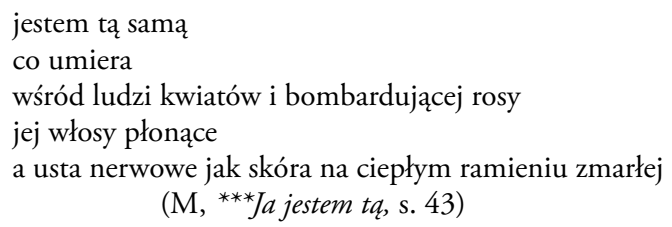

W przywołanym fragmencie - inaczej niż miało to miejsce w omówionym już czterowierszu — umieranie zostaje wyrażone jako czynność beznadziejnie niedokonana. „Ja” kona nieustannie, z każdą chwilą coraz intensywniej. Zachowanie ciała kobiety eksponuje widoczne symptomy zbliżającego się końca. Bohaterka Ostrowskiej, żyjąc „wśród ludzi kwiatów", spotykając się codziennie z bezlitosną sprawczynią ludzkiego umierania, postanawia samodzielnie położyć kres swojej egzystencji. Patrząc śmierci w oczy, nie chce pozwolić jej na zwycięstwo. W umyśle bohaterki wiersza dokonuje się więc wewnętrzna przemiana. Dochodzi do transgresji:

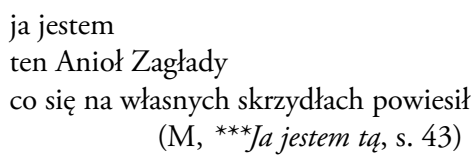


Anioł zagłady (stworzenie, które uśmierca, zabija i eksterminuje) to upadła istota boska. Sprzeciwiając się Bogu, doprowadza do samounicestwienia. Umysłowa transgresja kobiety-wariatki w demona zabijającego samego siebie (zapewne dokonująca się w świecie narkotycznych halucynacji), doprowadza „ja” do aktu samobójczego, jak się później okaże nieudanego ${ }^{18}$.

Równowaga człowieka ulega zachwianiu, kiedy dowiaduje się on zbyt wiele na temat samego siebie. „Sięga wzrokiem zbyt daleko i widzi zbyt wiele” ${ }^{19}$, za dużo myśli, co odbiera mu zdolność spontanicznej radości, a kieruje umysł — jak pisał Chwin — ku tanatycznej kontemplacji. Doprowadza ona jednostkę do granicznego doświadczenia albo przekroczenia granicy śmierci. Osoba, której udaje się sięgnąć w głąb człowieczeństwa, cierpienia, piekła swojej duszy, odrzucając świat, znajduje określone czyny i miejsca. Dzięki nim — jak stwierdził Wilson — uzyska siłę przezwyciężenia wątpliwości i ustawicznie stawianych sobie pytańn ${ }^{20}$.

Ostrowska jest poetką, która — w przeciwieństwie do ostrzeżenia wypowiedzianego przez Chwina - zbyt wiele wie o mrocznych stronach życia, widzi to, czego nie powinna widzieć, silniej odczuwa ból oraz przekracza wyznaczoną granicę ryzyka ${ }^{21}$. Odrzucona przez społeczeństwo jako autentyczny obcy, outsiderka myśli o śmierci. Ma świadomość umierania, oczywistej przemijalności, co wyraża nie tylko w poezji, ale także w dzienniku. Pod datą 26 czerwca 1981 roku autorka Echolalii zapisała:

Nie można żyć w świecie sztuki — kolorowych pasaży, nie ma świata sztuki, jest świat bólu i realizacji to jeden i ten sam świat.

$[\ldots]$

Widzisz, ja sama dla siebie nie widzę sensu zapięcia sukni, kiwnięcia palcem, wszystko, co robię, to ze względu na innych, dzięki innym, dla siebie samej nie pragnę żyć, jeśli tak długo umieram, to ze względu na Ciebie, na innych, żeby jeszcze przez chwilę siebie Wam darowywać (to nie altruizm, raczej egoizm).

$[\ldots]$

Tyle smutku i zwątpienia, że aż nie wiem, czy warto się smucić, żyć, nie traktuj tego, do cholery, jak ekshibicjonizm, nie użalam się nad sobą, stwierdzam tylko ból i cichą śmierć, nie od dziśs, ale właśnie uświadamiam konkretny ból i projekcję bólu. [...] Żeby wyjść z bagna, trzeba pragnąć na nim stanąć i trzeba mieć wspomnienie i tęsknotę za tym luksusem, idealnym ubóstwem.

[...] Jestem już prawie pijana, a jednak łzy, lęk i rezygnacja wciąż mają do mnie dostęp, wciąż jestem nadto trzeźwa i nadto uparta, by przyjąć śmierć... ale kiedyś (czyżby bardzo niedługo?) odejdę poza jakiekolwiek odczuwanie i zrozumienie, wtedy przestanę uświadamiać sobie ból (to nie jest groźba, tylko stwierdzenie tego, co stać się musi, inaczej wszystko musiałoby mieć więcej sensu niż bezsensu) ${ }^{22}$.

\footnotetext{
${ }^{18}$ Poszerzoną interpretację utworu rozpoczynającego się od słów *** Ja jestem można znaleźć w: K. Niesporek, $d z$. cyt.

${ }^{19}$ C. Wilson, dz. cyt., s. 17.

${ }^{20}$ Tamże s. 77.

${ }^{21}$ Por. S. Chwin, $d z$. cyt., s. 124.

${ }^{22}$ E. Ostrowska, $d z$. cyt., s. 172-175.
} 
Dla Ostrowskiej przestrzenią ukojenia w przymusie życia i bólu istnienia jest rzeczywistość narkotyczna, wędrówka przez kolejne, coraz bardziej niebezpieczne fazy narkotycznej ekstazy. To po zażyciu psychoaktywnych środków bohaterka utworów spotyka się ze śmiercią, spogląda jej w oczy, ale też nie pozwala się jej ubezwłasnowolnić. Zamyka się więc w przestrzeni „pomiędzy”. Trwając w stanie „zawieszenia”, igra zarówno z życiem, jak i śmiercią.

"Ja”, zaliczając się do chorych psychicznie, dewiantów, narkomanów i ekscentryków, ginąc w tłumie, wciela się w widmo (na co wskazuje także wygląd ciała). Jest istotą umarłą dla świata, ale wciąż świat ten przenikającą. Bohaterka wierszy nie ma odwagi, aby ostatecznie opowiedzieć się po stronie śmierci. Wcielenie w widmo umożliwia egzystencję na krawędzi oraz nierezygnowanie z życia.

Z narkotykami Ostrowska połączyła również Boga, uświęcając „białe proszki” — powszedni chleb dzieci-kwiatów. Ekscentrycy mają prawo do świętości, podobnie jak do narkotycznych modłów. To Bóg jest stwórcą śmiercionośnych substancji, których deficyt $\mathrm{w}$ organizmie uzależnionego prowadzi do narkotycznego głodu (którym — w przypadku poetki — jest także pragnienie porozumienia się ze światem). Narkoman najbardziej czuje w takich momentach, że umiera i staje przed koniecznością przejścia na drugą stronę. Wtedy jednak istnieją już tylko dwie możliwości: albo Bóg łaskawie zechce go uratować, zsyłając narkotyczną mannę z nieba, albo nie czekając na boskie zmiłowanie, wychodząc śmierci naprzeciw, popełni samobójstwo. Autorka Baranka zabitego wybiera drugie wyjście. To jednak prowadzi ją ponownie do życia.

Katarzyna Niesporek

\section{About the Experience of Death in Eda Ostrowska's Poetry}

\section{Summary}

Eda Ostrowska is a poet who contemplates death of her life. In the words of Stefan Chwin from the book Suicide as an Experience of Imagination, Ostrowska knows too much about the dark side of life, sees what she shouldn't, strongly feels the pain and exceeds the designated limit of the risk. Ostrowska is rejected by society as a genuine stranger, the outsider still thinking about death. She has a strong awareness of dying, obvious transience which she expresses not only in the poetry but also in the diary I Stand in Front of You in the Body Rain. Lonely, misunderstood by people Ostrowska is living, but constantly dying. Convinced of the value of being on the other side but not having the courage to end up with her life, she finds narcotic alternative spaces which allow her to exist on the edge, to dice with death and life. 